\title{
The Silver Castle Revisited-A Few Notes
}

\author{
Henk Blezer
}

Leiden University

\begin{abstract}
After "Heaven my Blanket, Earth my Pillow" appeared in Acta Orientalia, ${ }^{1}$ additional information has become available, which renders it both useful and necessary to revisit the topic. First, in fall 2008, in Redna Menling, ${ }^{2}$ I found the opportunity, in three hours of recorded interviews, to speak about the topic of the article to the learned 'Me me' mKhas mchog rdo rje, a long-time resident in the Khyung lung area and one of the last living disciples of Khyung sprul Rin po che (1897-1955); also known as Ga rgya 'Jigs med nam mkha'i rdo rje. Additional relevant publication also has appeared in the Samten Karmay felicitation volume: ${ }^{3}$ a contribution by Roberto Vitali on the bya ru can kings of Zhang zhung incidentally also comments on the location of Khyung lung dngul mkhar, ${ }^{4}$ and, in the same volume, there is an article by Charles Ramble ${ }^{5}$ on dKar ru grub dbang bstan 'dzin rin chen (b. 1801) - who, to our present knowledge, was the first person to record the Gur gyam mKhar gdong ri location of Khyung lung dngul mkhar in writing.
\end{abstract}

$1 \quad$ Acta Orientalia (Vol. 68), pp. 75-112.

2 A bonpo nunnery affiliated to Menri Monastery, H.P., India.

3 Achard et al., in Revue d'Etudes Tibétaines (RET), vols. 14 and 15, Paris 2008.

4 RET, Vol.15, pp. 379-419 and see particularly the section on "The bya ru can kings of Khyung lung and the local seats of secular and religious power," on pp. 407-9.

5 RET, Vol. 15, pp. 481-501. 


\section{Separating the Sacred and the Profane}

Vitali forwards a truly fascinating and also very original hypothesis, which to my knowledge had never been argued before. Mainly based on two passages from the Gangs ti se'i dkar chag, he distinguishes both a religious center and a castle in Khyung lung. The Khyung chen spungs pa'i ri near Gur gyam, which is also called mKhar gdong ri, he believes is a religious center and perhaps the seat of a (legendary) Bon ' $d u l b a$ master. However, Khyung lung dngul mkhar, the stronghold and residence of the Khyung lung bya ru can rulers and later the Lig myi rhya dynasty, he places much further west (where Tucci also put it): not far from the present-day Khyung lung yul smad village. Based on Vitali's evidence, separation of the two seems possible if not, indeed, plausible!

His conclusion is mainly based on a brief note to a passage in the Gangs ti se'i dkar chag. ${ }^{6}$ He edits and translates the passage. Khyung chen spungs pa'i ri is mentioned and glossed there as mKhar gdong ri. Khyung lung dngul mkhar is not mentioned there, but only slightly later. Vitali thus argues that the distinction he proposes was also made by dKar ru grub dbang, when he (himself?) added this note to the $d k a r$ chag, which latter presumably is based on now lost older sources. Vitali finds confirmation in (his reading of) a later passage (p. 598.6), where he takes the particle "dang" in khyung chen spungs pa'i ri dang khyung lung dngul mkhar to imply separation of the two listed entities. He believes that his view was also shared by Khyung sprul Rin po che, who built his monastery in Gur gyam near mKhar gdong ri and Khyung chen spungs pa'i ri for that very reason. In Vitali's analysis, modern-day bonpo savants, who hold different views, may have reformed that older understanding and thus have ignored the opinions of authorities on the matter and their indications in sources. Based on the evidence that Vitali adduces, his argument indeed appears plausible, or at least defendable. But I should like to adduce additional written and oral evidence that strongly suggests that both dKar ru grub dbang and Khyung sprul Rin po che already unambiguously identified mKhar gdong ri as the Khyung lung dngul mkhar site.

6 Gangs ti se'i dkar chag (Dolanji 1973), p. 576.7. 


\section{Closing the Gap}

If we refer to another pertinent passage in the Gangs ti se'i dkar chag, ${ }^{7}$ it becomes clear that the newly suggested possibility indeed goes counter to dKar ru grub dbang's own ideas on the matter. dKar ru grub dbang writes in this section of his dkar chag that in the northern direction of Zhang Zhung there is "khyung chen spungs pa'i ri khyung lung dngul mkhar." So far no problem - if we would read this phrase, as indeed does Vitali, as referring to two separate locations. But here, too, an added note appears: Khyung lung dngul mkhar is unambiguously glossed as mKhar gdong ri! ${ }^{8}$ Moreover, in this light, the fact that Khyung chen spungs pa'i ri and Khyung lung dngul mkhar here appear in apposition, as names connected to the same place, assumes greater significance.

Needless to say, when viewed in this light, the identity of the Khyung chen spungs pa'i ri location and the whereabouts of Khyung lung dngul mkhar are not at all put into question by the passage that Vitali quoted (dKar chag p. 576.5-577.2). ${ }^{9}$ When we consider both notes together, the identity seems rather emphatically confirmed. The fact that Khyung chen spungs pa'i ri and Khyung lung dngul mkhar are both glossed as mKhar gdong ri, can only be read in such a way that according to dKar ru grub dbang both were in the same location: mKhar gdong ri. They must therefore consciously have been joined in apposition: khyung chen spungs pa'i ri [=] khyung lung dngul mkhar. This is confirmed by local and otherwise received wisdom (e.g., as related by several students of Khyung sprul Rin po che).

These data need to be related to Vitali's further evidence that the two names may pertain to two discrete and different places. He quotes a complex passage on the sub-classification of Zhang zhung sgo, phug, and bar (its gate, inner and intermediate parts), again, into three each: g-yas, g-yon, and dbus (right, left and center). These are again divided into sgo, phug, and bar. Khyung chen spungs pa ri and Khyung lung dngul mkhar appear at dbus sgo phug. ${ }^{10}$ Vitali reads the

7 Gangs ti se'i dkar chag (Dolanji 1973), p. 513.5f.

8 See p. 82, n. 14 in Acta Orientalia 68.

9 Where only Khyung chen spungs pa'i ri is mentioned, which there is (also) glossed as mKhar gdong ri.

10 Gangs ti se'i dkar chag (Dolanji 1973), p. 598.6f.: de ltar du'ang dbus sgo ni/ 
particle "dang" to imply separation, but that need not necessarily be implied there. Unlike in the previous sections, ${ }^{11}$ here and in the two following lemmas (dbus sgo bar and sgo), dKar ru grub dbang simply enumerates locations together with the buildings or structures associated with them and no significant geographical separation seems to be implied; certainly not something of the order of magnitude of the distance between Gur gyam and Khyung lung yul smad. The names in these pairs pertain to different categories: one is a geographical matrix in the landscape: e.g. a mountain; the other a structure erected in or near those whereabouts: e.g., a castle. So, quite to the contrary, the fact that these pairs are here listed together implies that they were thought to have been located approximately in the same area, a bit like Ti se and Ma pang are, but closer.

In the geographical layout of the passage that Vitali quotes on the spread of 'dul ba bon teaching there also already is a clear indication for the identity of the Khyung chen spung pa'i ri/ mKhar gdong ri and the dNgul mkhar dkar po sites: both are located in grong khyer rGyal ba mnyes yul. ${ }^{12}$ Even though the way Vitali translates the passage may perhaps suggest otherwise, the Tibetan is quite unambiguous about the matter. Khyung chen spung pa'i ri/mKhar gdong (ri) khab and the dNgul mkhar dkar po are supposed to be in the same grong khyer: city, citadel, or something like that; it is highly unlikely that both Khyung lung yul smad and Gur gyam mKhar gdong ri locations, quite far apart indeed, could be considered to be included in one grong khyer.

Also Khyung sprul Rin po che, much later, in the biography by

phug khyung chen spungs pa'i ri dang khyung lung dngul mkhar//

bar lha ri g-yang do dang rgyal mkhar gying/

sgo she le rgya gar dang khyung po gting rdzong sogs gsum mo/.

11 Cf. for instance g-yon sgo phug, a few where adjacent pairs of lakes and mountains appear (ib., 11.5f.).

12 Gangs ti se'i dkar chag (Dolanji 1973), p. 576.5-577.2, de ltar du'ang YE SHES TSHUL KHRIMS kyi slob ma/ DRANG SRONG G.YUNG DRUNG TSHUL KHRIMS zhes bya ba des! ZHANG ZHUNG KHYUNG LUNG gi grONg KHYER RGYAL BA MNYES YUL gyi khab KHYUNG CHEN SPUNG PA'I RI [note: MKHAR GDONG zer] la yang / dgra bcom g-yung drung sems dpa'i [p. 577] 'dus sde grangs med du bstan pa spel la/ de'i dus su'ang zhabs nas 'deg pa'i rgyal po/ grong khyer RGYAL BA MNYES YUL gyi DNGUL MKHAR DKAR PO khro chu'i rmengs rdo can de ru yang/ SLAS KRA GU GE'I RGYAL PO rin chen 'od kyi bya ru can nyid do//. 
dPal ldan tshul khrims, is quite explicit about the fact that he thought that Khyung lung dngul mkhar was located on top of the flat mesa called mKhar gdong ri. Probably the most clear and unambiguous reference appears when Khyung lung dngul mkhar sdong (gdong) is mentioned ( $b K a^{\prime}$ brten, vol. 273, p. 405, 1.3)! Khyung sprul Rin po che's understanding of the location appears quite unambiguously from other passages also. All in all, there is no indication for a drastic reform or radical change by modern bonpo masters and savants of older understandings of dKar ru grub dbang and Khyung sprul Rin po che of the sites, as Vitali concludes. If we review all the evidence, these assumptions immediately evaporate, as artifacts of translation and incomplete evidence.

Lastly, the reference to khro chu (something like molten metal) in relation to the site of castle, in its qualification khro chu rmengs do can, needs further comment as well. ${ }^{13}$ This phrase was another reason for Vitali to connect the castle to Khyung lung yul smad, to the west, and not to Gur gyam mKhar gdong ri, because khro chu supposedly is not in evidence in mKhar gdong ri, but may be near Khyung lung yul smad, in the form of the well-known sulfurous springs in its vicinity. However, one of the few surviving students of Khyung sprul Rin po che, mKhas mchog rdo rje, who copied down dPal tshul's biography of Khyung sprul Rin po che, tells me that he has had to presume that whatever was on top of mKhar gdong ri was destroyed by fire, because they found traces of fire and molten metal all over! The mesa of mKhar gdong ri, also in that respect, provides a far better match than the 'far-fetched' sulfurous springs near Khyung lung yul smad. Needless to say, as I have argued in Acta Orientalia, I nonetheless think that we have sufficient reason to question both the Khyung lung yul smad and Gur gyam mKhar gdong ri locations.

\section{A Few Corrections}

1) Acta Orientalia 68, p. 82, n. 14 quotes dKar ru's birthplace near Ti se and the place of composition of his Gangs ti se'i dkar chag (from the introduction to the edition by Prats and Norbu, Roma 1989). But, as Ramble (2008)

13 Referring again to the Gangs ti se'i dkar chag (Dolanji 1973), p. 577.1f.; see the full quote above. 
rightly points out, these data are probably incorrect, or provide an alternative tradition at best. According to dKar ru's own biography (in Ramble's words): he was born in "the town of Sog sde bon dgon, which is located in the valley named Khra zhu, in the east of the savage borderland of Hor (in Khams)" and he wrote his Gangs ti se'i dkar chag near Dang ra (see Ramble RET, Vol. 15, p. 483 and n. 2; and p. 493, n. 11, successively).

2) P. 87: Khyung sprul Rin po che did not end up travelling with but to Tshab shi Nyi ma grags pa (who by then also was too old to travel extensively). The companion who traveled with Khyung sprul Rin po che was another student of the same root teacher, sPa btsun Nyi ma 'bum gsal (b. 1854), called Se dor bon nyid rgyal mtshan (see references in Khyung sprul's rnam thar, $b K a^{\prime}$ brten, vol. 273, on pp. 221.5ff. and p. 243.1f.). Se dor bon nyid rgyal mtshan passed away during a brief break in their travels, apparently on an ill-fated solo journey to sPu hrang, while enjoying the hospitality of a local nomad (religious euphemisms for his passing appear on p. 413.5ff.). Khyung sprul Rin po che subsequently goes there, together with a male assistant, to perform the appropriate death rites and sky burial (p. 414).

3) P. 90 contains an anachronism: when sPa btsun Nyi ma 'bum gsal advised Khyung sprul, "true to his name", on proposed pilgrimage itineraries, Khyung sprul was not yet named thus. A Nyingma lama, Degya Rinpoche(?), started the Khyung moniker later, after the former had established or 'revealed' his Khyung lung-connections, during his activities in western Tibet (he also gave him the name 'Jigs med nam mkha' rdo rje). Earlier he was called g-Yung drung rgyal mtshan dpal bzang. Many thanks go to mKhas mchog rdo rje (interview 2008) for this and other information. 